FILOZOFIA

Roč. 75, 2020, č. 3

DOI: https://doi.org/10.31577/filozofia.2020.75.3.2

\title{
APPIUS CLAUDIUS CAECUS A POČIATKY RÍMSKEJ FILOZOFIE
}

PETER FRAŇO, Katedra filozofie a aplikovanej filozofie, Filozofická fakulta Univerzity sv. Cyrila a Metoda v Trnave, Trnava, SR

FRAŇO, P.: Appius Claudius Caecus and the Beginnings of Roman Philosophy FILOZOFIA, 75, 2020, No 3, pp. $183-194$

\begin{abstract}
The paper deals with the interpretation of the thought of Appius Claudius Caecus, who, according to tradition, belongs to the first Roman philosophical authors. At the beginning of this paper, the author presents four models of interpretation of the beginnings of Roman philosophy (historical and cultural, idealizing, class, literary) in the thinking of Marcus Tullius Cicero. Later the author deals with the thinking of Appius Claudius Caecus in two issues. The first group of problems concerns the association of Appius Claudius Caecus thinking with the philosophy of Pythagoreism. The second group of problems concerns the status of this author in the interpretation of the beginnings of the history of Roman philosophy.
\end{abstract}

Keywords: Appius Claudius Caecus - Pythagoreanism - Cicero - Roman philosophy

Výklad dejín akéhokol'vek filozofického obdobia sa vždy začína určením nejakého počiatočného periodizačného míl'nika. Väčšinou sa uvažuje o konkrétnych osobnostiach či historických a kultúrnych udalostiach, ktoré výstižným spôsobom reprezentujú prelomový charakter spoločenských a názorových zmien v novo nastupujúcej ére. Prvé pokusy o ich určenie sú väčšinou prítomné už v textoch súdobých autorov, ktorí s určitým časovým odstupom hodnotia dejinný význam svojich priamych predchodcov. V prípade počiatkov gréckej myšlienkovej tradície je takýmto autorom bezpochyby Aristoteles, ktorý v známej pasáži z prvej knihy Metafyziky (Arist. Met. 983b), označí za prvého pôvodcu filozofického uvažovania Thaleta $z$ Milétu. ${ }^{1}$ Hoci sa o tomto názore vedú pomerne rozsiahle akademické polemiky, ${ }^{2}$ postava Thaleta sa vo

\footnotetext{
${ }^{1}$ Okrem Aristotelovej autority zohráva pri určení „Thaletovho prvenstva“ dôležitú úlohu aj fakt, že práve k jeho osobe sa viaže aj konkrétny historický dátum (28. máj roku 585 pred n. 1.), ked’ mal údajne predpovedat' zatmenie Slnka (DK 11 A 5).

${ }^{2}$ Matúš Porubjak napríklad nachádza počiatky protofilozofického myslenia už v starej gréckej elégii (Porubjak 2012, 35 - 46; 2013, 276 - 284).
} 
všeobecnom filozofickom povedomí stala synonymom počiatočného periodizačného míl'nika.

Keby sme chceli podobný myšlienkový postup uplatnit' aj v prípade rímskej filozofie, tak zistíme, že prvé relevantné svedectvá o svojich filozofických predchodcoch nám poskytuje až Marcus Tullius Cicero (106 - 43 pred n. 1.). Cicero sa však pozerá na problém vzniku rímskej filozofie nejednotne, cez prizmu rôznych metodických východísk. V jeho literárnej pozostalosti sa preto celkovo môžeme stretnút' až so štyrmi odlišnými prístupmi $\mathrm{k}$ tejto problematike.

\section{Počiatky rímskej filozofie}

Z historicko-kultúrneho hladiska je Cicero presvedčený o tom, že vznik rímskej filozofie umožnili až spoločenské zmeny v oblasti Stredomoria, ktoré nastali v priebehu 2. storočia pred n. 1. V tomto období Rimania vojensky dobývajú grécke územie a zoznamujú sa s helénskym myšlienkovým dedičstvom. Filozofia ako grécky import sa postupne etabluje $\mathrm{v}$ intelektuálnych kruhoch niektorých vysoko postavených politikov (napr. u Scipiona Aemiliana), ktorí sa priamo stávajú patrónmi prvých filozofujúcich literátov (napr. dramatika Publia Terentia Afera či satirika Gaia Lucilia). ${ }^{3}$ V kontexte uvažovania o týchto literátoch sa vel'mi často poukazuje na existenciu takzvaného Scipionovho krúžku (lat. grex Scipionis) ako akéhosi prvého filozofického programového zoskupenia, ktoré by sa ako celok teoreticky mohlo uchádzat' o status periodizačného míl'nika. Niektorí moderní bádatelia však presvedčivo poukazujú na skutočnost', že existencia tohto zoskupenia je skôr literárnou fikciou autorov 19. storočia, ktorú nekriticky prevzali od Cicera. ${ }^{4}$ Okrem toho v roku 155 pred n. 1. dochádza v Ríme k verejnému predstaveniu gréckych filozofických náuk. Do Ríma vtedy ako aténsky diplomatickí vyslanci ${ }^{5}$ prichádzajú predstavitelia troch najvýznamnejších dobových filozofických smerov - akademik Karneades, stoik Diogenes Babylonský a peripatetik Kritolaos. ${ }^{6}$ Pre dejiny výskumu počiatkov rímskej filozofie je dôležitý najmä fakt, že podl'a niektorých antických svedectiev (Quint. Instit. XII, 1, 35; Lact.

\footnotetext{
${ }^{3}$ K filozofickému významu Terentia a Lucilia pozri bližšie: Sharrock (2013, 63 - 66); Mendell (1920, 138 - 157); Raschke (1990, 352 - 369).

${ }^{4}$ Strasburger (1966, 60 - 72); Zetzel (1972, 173 - 179); Forsythe (1991, 363 - 364).

${ }^{5}$ Vol'ba filozofov za diplomatických vyslancov nebola v helenistickom období nezvyčajná. Napríklad akademický filozof Dión z Alexandrie (1. storočie pred n. 1.) bol vyslaný do Ríma ako diplomat s ciel'om presvedčit' senát, aby neumožnil znovunastolenie egyptského faraóna Ptolemaia XII. na trón. ${ }^{6}$ Pozri najmä Plu. Cat. Ma. 22; Plin. Nat. VII, 30; Cic. de Orat. II, 37, 154 - 38, 161; Luc. 137; Lact. Div. inst. V, 14; Gel. VI, 14. Dôvodom ich príchodu bola žiadost' o zrušenie rozsudku, podl'a ktorého mali Aténčania zaplatit' pokutu 500 talentov za vyplienenie mesta Órópos (pozri Paus. VII, 11). Vo vyslanectve neboli prítomní zástupcovia epikurejcov. Rimania sa totiž vo väčšine prípadov negatívne vymedzovali voči tejto filozofickej škole. $Z$ roku 154 pred n. 1. máme napríklad zachované informácie o vyhnaní dvoch epikurejcov Alkia a Filiska z Ríma (Ath. XII, 547a; Ael. VH, IX, 12).
} 
Div. inst. V, 14, 3 - 5; Epitome 50, 5 - 8) mal Karneades práve počas pobytu v Ríme verejné prednášky o spravodlivosti, ktoré následne vel'mi ovplyvnili rímsku mládež. A práve v tomto verejnom predstavení gréckej filozofie vidia aj viacerí moderní autori historický medzník v počiatočnom vývoji rímskej filozofie. ${ }^{7}$ Druhé storočie predstavuje pre Cicera skutočné saeculum mirabile vo vývoji rímskej filozofie, a preto v spise Tuskulské rozhovory neváha úplne otvorene konštatovat', že práve pred obdobím života Scipiona Aemiliana a Gaia Laelia nenachádza v rímskom prostredí žiadneho iného filozofujúceho autora (Cic. Tusc. IV, 3, 5).

Rímsky filozof si však reálne uvedomuje, že zastávanie tohto historického východiska, podla ktorého sa filozofia javí ako pomerne mladá disciplína, ${ }^{8}$ nadobúda problematické črty vtedy, ked' má byt' ciel'om výkladu obhajoba intelektuálnej starobylosti rímskej kultúry. Preto rozvíja v niektorých svojich dielach aj druhé idealizujúce stanovisko. $\mathrm{V}$ ňom sa rímska filozofia interpretuje ako myšlienkové pokračovanie „domácej“, teda pytagorejskej tradície (Cic. Tusc. IV, 1,2). Ked’že pytagorejci žili a tvorili v gréckych mestách na juhu Itálie, dalo sa l'ahko poukázat' na to, že medzi nimi a niektorými italickými kmeňmi (najmä Samnitami) ${ }^{9}$ mohlo dochádzat' v ranej fáze vývoja rímskej spoločnosti $\mathrm{k}$ nejakej forme kultúrnych kontaktov. ${ }^{10}$ Tieto archaizujúce tendencie sa $\mathrm{v}$ oblasti filozofie spájajú najmä s menami legendárneho druhého rímskeho král'a Numu Pompilia (pozri Plu. Num. 8; Aem. 2; Liv. XL, 29), politika Appia Claudia Caeca (pozri Cic. Tusc. IV, 2, 4) a samnitského vojvodcu Herrenia Pontia (pozri Cic. Sen. 12, 39 - 41).

Tretie stanovisko zdôrazňuje rozmer triednosti. V Cicerovom ponímaní filozofia reprezentuje oblast' intelektuálneho záujmu, ktorá je vyhradená výlučne vysoko postaveným vrstvám rímskej spoločnosti. Autor preto $\mathrm{v}$ súvislosti s počiatkami filozofie neváha uvádzat' mená Scipiona Aemiliana, Gaia Laelia či Appia Claudia Caeca, no na druhej strane problematizuje napríklad Enniov prínos. ${ }^{11}$ Cicero síce rešpektuje Ennia ako filozofického autora, no $\mathrm{k}$ jeho výraznému preferovaniu $\mathrm{v}$ rámci zmienok o počiatkoch dejín rímskej filozofie nedochádza. Dôvod zastávania tohto stanoviska súvisí podl’a Doroty Dutschovej najmä s Enniovým neprimeraným spoločenským

\footnotetext{
${ }^{7}$ Pozri Morford $(2002,14)$; Griffin $(2005,3)$; Ku kritike uskutočnenia verejných prednášok v Ríme pozri Powell (2003, 219 - 247).

${ }^{8}$ O problematickom vzt'ahu rímskej spoločnosti k filozofii svedčí aj skutočnost', že Rimania prebrali od Grékov filozofickú spisbu až ako úplne posledný literárny žáner.

${ }^{9}$ K otázke vplyvu Samnitov na recepciu rímskeho filozofického myslenia pozri bližšie Horky (2011).

${ }^{10}$ Je zaujímavé, že rímska tradícia uvažovala o nadväzovaní vzájomných interkulturálnych kontaktov len v prípade pytagorejcov, a nie u Empedokla či eleatov, ktorí taktiež pôsobili na juhu Apeninského polostrova či na Sicílii.

${ }^{11} \mathrm{~V}$ jeho dielach Euhemerus či Epicharmus môžeme identifikovat' viacero filozofických prvkov. Pozri Maurach (2006, 14 - 19), Dutsch (2014, 5 - 10).
} 
postavením. Ked’že Quintus Ennius pochádzal z neurodzeného rodu a pôsobil v Ríme ako grammatikos či dramatik, ktorý vždy žil pod patronátom iných osôb, preto ho z hl'adiska triednosti nemožno zaradit' do panteónu prvých rímskych filozofov. Toto povolanie je v Cicerových očiach exkluzívne vyhradené najvyšším vrstvám rímskej spoločnosti (principes, optimates), do ktorých patrili už aj spomínaní Scipio či Laelius. Títo autori síce nepísali filozofické diela, no svojím životom na dlhé obdobie vytvorili štandardy správania sa $\mathrm{v}$ rámci rímskej morálnej praxe (Dutsch 2014, 2 - 5). A ked’že praktická, eticko-politická stránka filozofie má v Cicerovom uvažovaní vždy ovel'a väčšiu hodnotu ako jej teoretické vymedzenie, títo autori predstavujú pre rímskeho myslitel’a ideálnych reprezentantov archaického filozofického spôsobu života. ${ }^{12}$

Posledná, štvrtá pozícia berie do úvahy najmä literárne kritériá. Pre Cicera filozofická tvorba predstavuje špecifický literárny žáner, ktorý je spätý výlučne s prózou. To znamená, že ani epik Ennius, ani satirik Lucilius, ani dramatici Plautus a Terentius nemôžu byt' v tomto špecifickom zmysle slova považovaní za filozofujúcich autorov. Za naozaj prvého skutočného filozofa tak možno v konečnom dôsledku označit' až samého Cicera, ktorý tak svojimi prozaickými traktátmi, ako aj odbornou terminológiou sprístupnil grécku filozofiu rímskemu publiku. ${ }^{13}$ Užívanie prózy sa totiž tradične pokladá za jeden $\mathrm{z}$ dôležitých znakov nového racionalistického prístupu $\mathrm{k}$ svetu. ${ }^{14}$ Preto si Cicero tak vel'mi zakladá na tom, aby jeho prínos $\mathrm{k}$ tejto oblasti nebol príliš opomenutý (Cic. Tusc. I, 3, 5-6).

Uvedené interpretačné modely určujú pre počiatky rímskej filozofie jednak rôzne chronologické rozhrania (historicko-kultúrny prístup: 2 . storočie pred n. 1.; idealizujúci prístup: $4-3$ storočie pred n. 1.; literárny prístup: 1 . stor. pred n. 1.), a jednak aj rozmanité východiskové míl'niky (personálne: Marcus Tullius Cicero, Appius Claudius Caecus; dátumové: rok 155 pred n. 1.; kultúrne: existencia grex Scipionis; triedne: principes, optimates). Ked’že z hl'adiska predmetu nášho skúmania je vždy t’ažšie obhájit' stanovisko, ktoré situuje určenie počiatočného periodizačného míl'nika do najstaršieho obdobia, $\mathrm{v}$ d’alšom výkladovom postupe sa zameriame práve na interpretáciu chronologicky najstaršieho, teda idealizujúceho postoja. Ak chceme zároveň relevantným spôsobom uvažovat' o tejto problematike, tak v prvom rade musíme brat' do

\footnotetext{
${ }^{12}$ Napríklad v spise Paradoxa stoicorum Cicero filozoficky interpretuje cnostné správanie sa starých zákonodarcov (Romulus, Numa Pompilius, Lucius Iunius Brutus), vojvodcov (Gaius Mucius Scaevola, Publius Horatius Cocles, Publius Decius Mus, Marcus Regulus, Gaius Marius) a spravodlivých a skromných štátnikov (Gaius Fabricius Luscinus, Marcus Porcius Cato, Manius Curius Dentatus) (Cic. Parad. 6 - 19).

${ }^{13}$ K významu Ciceronovej filozofickej terminológie pozri Urbancová (2003, 513 - 522).

${ }^{14} \mathrm{Na}$ základe tohto predpokladu napríklad Pavel Hobza spochybňuje filozofický prínos Milét’anov (Thales, Anaximandros, Anaximenés. Pozri Hobza (2007, 23 - 34).
} 
úvahy zachovanú primárnu textovú tradíciu. $Z$ troch vyššie spomenutých autorov (Numa Pompilius, Appius Claudius Caecus, Herrenius Pontius), ktorí sa v rímskom literárnom prostredí tradične spájali s najstaršou, pytagoreizmom ovplyvnenou filozofiou, sa nám však do dnešných čias zachovali iba texty Appia Claudia Caeca. Oprávňujú nás teda tieto texty hovorit' o Appiovi ako o pytagorejskom filozofovi? A môžeme Appia naozaj pokladat' za jedného z predstavitel'ov ranej rímskej filozofickej tradície?

\section{Appius Claudius Caecus}

Život a dielo Appia Claudia Caeca (prelom 4. a 3. stor. pred n. 1.) sú poznačené viacerými idealizujúcimi tendenciami. Rímska literárna tradícia totiž do tejto osobnosti projektovala vzor vel'mi vzdelaného archaického mudrca, ktorý mal disponovat’ širokými praktickými a teoretickými znalost’ami. Appius vraj pôsobil ako skúsený politik a rétor. Na jeho podnet bola vybudovaná cesta z Capuy do Ríma a taktiež prvý akvadukt (Liv. IX, 29). Vd’aka nemu došlo k prvému spísaniu právnych postupov. Okrem toho zreformoval latinský pravopis a venoval sa d'alším rozsiahlym literárnym a kultúrnym záujmom (pozri Stankiewicz 2008).

Ako sme už spomínali, pre oblast' výskumu počiatkov dejín vývoja rímskej filozofie je dôležitá najmä tá skutočnost', že práve Appiovi vraj môžeme pripísat' autorstvo prvého diela s latinským filozofickým obsahom, ktorého názov mal zniet' Sententiae (Fest. p. 418L), Carmen (Cic. Tusc. IV, 2, 4) či Carmina (Sall. Epist. I, 1, 2), a z ktorého sa nám do dnešných čias zachovali iba tri krátke fragmenty: ${ }^{15}$

Fragment 1: Festus, p. 317 M (418 L)

...<ae>qui animi compotem esse, ne quid fraudis stuprique ferocia pariat.

„Vládni pokojnou mysl'ou, aby prudkost' nespôsobila žiadnu škodu a smilstvo “. 16

\section{Fragment 2, Priscianus, I 384 H}

amicum cum vides, obliscere miserias.

inimicus si es commentus ${ }^{17}$ nec libens aeque.

\footnotetext{
${ }^{15}$ Všetky latinské znenia troch Appiových fragmentov preberáme z kritického vydania Fragmenta Poetarum Latinorum Epicorum et Lyricorum (1927, 5 - 6).

${ }^{16} \mathrm{~V}$ texte štúdie použivame vlastné prozaické preklady Appiových fragmentov. V súlade s názorom Andreja Kalaša sa nazdávame, že ,prozaický preklad umožňuje presnejšie tlmočenie filozofického obsahu básnickej reči“ (Kalaš 2017, 115). Ak nie je v texte uvedené inak, tak aj všetky ostatné preklady z latinčiny a gréčtiny sú naše vlastné.

${ }_{17}$ Pri preklade tohto fragmentu sa pridŕžame anglického prekladu (Horky 2011, 141). Priscianus cituje tento Appiov zlomok, aby zdôvodnil, že latinské slovo commentus je ekvivalentom gréckeho termínu
} 
„Ked' vidíš priatel'a, zabudneš na strasti

[Ked' vidíš] nepriatel'a, tak ak si múdry, [nezabudneš na strasti] s rovnakou ochotou“.

\section{Fragment 3, Sallustius, ad Caes. Sen. De rep. 1, 1, 2}

fabrum esse suae quemque fortunae

„Každý si je strojcom vlastného osudu“.

Je zrejmé, že všetky tri fragmenty sa obsahovo vzt’ahujú k praktickej archaickej múdrosti. Prvý fragment zdôrazňuje význam zachovávania pokojnej mysle pred zhubným vplyvom „prudkosti“ (ferocia). Druhý fragment vyzdvihuje význam „múdrosti“ (commentus) ako dispozície, ktorá dokáže odlíšit' priatel'stvo od nepriatel'stva. A tretí fragment zasa akcentuje, že človek môže svojím životom aktívne formovat' vlastnú budúcnost'. Napriek nespornému protofilozofickému obsahu je však vel'mi problematické zo znenia týchto troch zlomkov si utvorit' celkový obraz o charaktere a ideových zdrojoch Appiovej filozofie.

Už v staroveku sa však u Marca Tullia Cicera objavil názor, podl’a ktorého môžeme tento spis spájat's filozofiou pytagoreizmu. Cicero dáva uvedené Appiovo literárne dielo do súvislosti s týmto myšlienkovým smerom výlučne v spise Tusculanae disputationes, kde explicitne píše:

Mihi quidem etiam Appi Caeci carmen, quod valde Panaetius laudat epistula quadam quae est ad $Q$. Tuberonem, Pythagoreum videtur.

„Pytagorejský ráz má podla mňa aj známa báseň Appia Caeca, ktorú v jednom liste Quintovi Tuberonovi vel'mi chválil Panaitios“ (Cic. Tusc. IV, 2, 4).

Uvedená pasáž sa nachádza v úvodnej časti štvrtej knihy Tuskulských rozhovorov, v ktorej sa Cicero zamýšl’a nad aktuálnym stavom filozofického bádania v domácom spoločenskom prostredí. A práve v záujme obhájenia starobylosti rímskej filozofie rozvíja idealistickú predstavu o tom, že pytagorejské myšlienky si Rimania od Grékov nielenže „osvojili, ale ich aj d’alej udržiavali a rozvíjali“ (expetita, sed etiam conservata et culta) (Cic. Tusc. IV, 1, 2). Z tohto dôvodu Cicero hl'adá "stopy“ (vestigia) kontinuity Pytagorovho učenia v rímskom geografickom priestore. Popri tradičnom

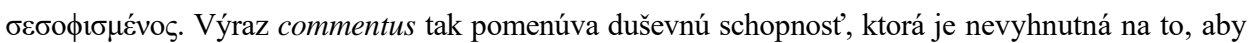
sme dokázali pochopit' rozdiel v interakcii medzi priatel'mi a nepriatel'mi (Horky 2011, 142). 
spájaní postavy druhého rímskeho krála Numu Pompilia s Pytagorom ${ }^{18}$ a popri hl'adaní analógií medzi rímskou obyčajou ${ }^{19}$ spievat' oslavné piesne v sprievode hudobného nástroja a pytagorejským zvykom vkladat' zásady filozofického učenia do básní, predstavuje práve väzba Appiovej básne na pytagoreizmus najdôležitejší argument v prospech platnosti tohto stanoviska. Problémom však je, že okrem subjektívnej domnienky (mihi quidem etiam) nám Cicero neposkytuje žiadne iné relevantné dôkazy o prepojení Appiovho diela s filozofiou pytagoreizmu. Otázkou preto ostáva, či v Appiovom diele naozaj môžeme nájst' nejaké „stopy“ pytagorejskej filozofie?

\section{Fragment 1}

$\mathrm{Z}$ troch spomínaných fragmentov sa s filozofiou pytagoreizmu tradične spája fragment 1 , ktorý sa nám zachoval v diele gramatika Sexta Pompeia Festa z 2. storočia n. 1. Na možnú súvislost' uvedeného fragmentu s filozofiou pytagoreizmu upozorňuje najmä francúzsky bádatel' Michel Humm. Odvoláva sa pri tom na znenie údajnej „starej reči“ (vetus oratio) pytagorejského filozofa Archyta z Tarentu, ktorú Cicero reprodukuje v spise Cato Maior de Senectute. Táto rozprava sa vraj mala odohrat' v roku 349 pred n. 1. medzi už spomínaným Archytom z Tarentu, samnitským vojvodcom Gaiom Pontiom a samým Platónom: ${ }^{20}$

Nullam capitaliorem pestem quam voluptatem corporis hominibus dicebat a natura datam, cuius voluptatis avidae libidines temere et ecfrenate ad potiundum incitarentur; hinc patriae proditiones, hinc rerum publicarum eversiones, hinc cum hostibus clandestina colloquia nasci; nullum denique scelus, nullum malum facinus esse, ad quod suscipiendum non libido voluptatis impelleret; stupra vero et adulteria et omne tale flagitium nullis excitari aliis inlecebris nisi voluptatis; cumque homini sive natura sive quis deus nihil mente praestabilius dedisset, huic divino muneri ac dono nihil tam esse inimicum quam voluptatem; nec enim libidine dominante temperantiae locum esse, neque omnino in voluptatis regno virtutem posse consistere.

\footnotetext{
${ }^{18}$ Táto kuriózna väzba sa pokladala už v antike za anachronickú. Napríklad v spise De re publica (Cic. Rep. II, 15, 28 - 29) Scipio dokazuje, že Pytagoras prišiel do Itálie až stoštyridsat' rokov po Numovej smrti (porov. Liv. I, 18; D. H. II, 59).

${ }^{19}$ Pytagoreizmus zdôvodňoval najmä starobylost' niektorých rímskych zvykov a obradov. V diele De agricultura spomína napríklad Cato špeciálny druh „,pytagorejskej kapusty“ (brassica Pythagorea) (Cato Agr. 157). Plinius zas píše, že Marcus Terentius Varro sa vraj dal pochovat',pytagorejským spôsobom“ (Pythagorico modo), teda s myrtou, olejom a listami čierneho topol'a (Plin. Nat. XXXV, 46).

${ }^{20} \mathrm{~K}$ otázkam datovania a bližšej charakteristiky aktérov a historického pozadia rozhovoru pozri bližšie Horky $(2011,120-122)$.
} 
„Povedal, že príroda nezoslala na l'udí zhubnejšiu pohromu ako rozkoš. Dychtivé vášne, ktoré ženú človeka $\mathrm{k}$ tomu, aby naplnil rozkoš, sú slepé a neskrotné. To je prameň vlastizrady, štátnych prevratov, tajných rokovaní s nepriatel'om. Neexistuje nijaký zločin, nijaká hanebnost', $\mathrm{k}$ spáchaniu ktorých by nepodnecovala zmyselná rozkoš. Znásilnenia, cudzoložstvá a všetky ostatné hanebnosti tohto druhu nie sú vyvolávané ničím iným ako nástrahami rozkoše. Na druhej strane príroda alebo nejaký boh nedali človeku nič lepšie ako rozum, avšak nič nie je pre tento božský dar väčším nepriatel'om ako rozkoš. Ved' tam, kde vládne lúbostná vášeň, nie je miesto pre umiernenost', a vôbec, v král'ovstve vášne sa cnost' nemôže udržat"“ (Cic. Sen. 12, 39 - 41).

Podobnosti medzi Appiovým zlomkom a Archytovou „starou rečou“ sú podla Michela Humma početné a zjavné a môžeme si ich schematicky znázornit' nasledujúcim spôsobom: ${ }^{21}$

\begin{tabular}{|l|l|}
\hline $\begin{array}{l}\text { Appius Claudius Caecus } \\
\text { (Sententiae) }\end{array}$ & $\begin{array}{l}\text { Archytas } \\
\text { (vetus oratio) }\end{array}$ \\
\hline compos animi & $\begin{array}{l}\text { temperantia = umiernenost' } \\
\text { avidiae libidines = dychtivé } \\
\text { vášne }\end{array}$ \\
\hline ferocia & $\begin{array}{l}\text { vlastizrada, štátne prevraty, } \\
\text { tajné rokovania s nepriatel'om }\end{array}$ \\
\hline $\begin{array}{l}\text { fraus (ujma pre toho, kto } \\
\text { zachováva fides) }\end{array}$ & $\begin{array}{l}\text { stupra et adulteria et omne tale } \\
\text { flagitium = znásilnenia, cudzo- } \\
\text { ložstvá a všetky ostatné haneb- } \\
\text { nosti tohto druhu }\end{array}$ \\
\hline $\begin{array}{l}\text { stuprum (hanebné správa- } \\
\text { nie) }\end{array}$ \\
\hline
\end{tabular}

Vidíme, že tak ako u Appia môže z „prudkosti“ (ferocia) vzniknút’ „škoda“ (fraus) a „smilstvo“ (stuprum), rovnako u Archyta vznikajú z „dychtivých vášni““ (avidiae libidines) neresti spadajúce tak pod kategóriu fraus (,vlastizrada, štátne prevraty, tajné rokovania s nepriatel'om") (patriae proditiones, rerum publicarum eversiones, hinc hostibus clandestina colloquia), ako aj neresti, ktoré sa týkajú kategórie stuprum (,znásilnenia, cudzoložstvá a všetky ostatné hanebnosti tohto druhu“) (stupra vero et adulteria et omne tale flagitium). Vplyvu prudkosti zároveň u Appia vzdoruje „,pokojná mysel““ (compos animi) a u Archyta ,umiernenost““ (temperantia) (Humm 2005, 532 - 533).

${ }^{21}$ Uvedenú schému preberáme zo staršej talianskej štúdie Michela Humma (2000, 455), ktorá sa mierne odlišuje od autorovej novšej podoby uverejnenej v knihe Humm $(2005,533)$. Text je mierne upravený a doplnený o slovenské výrazy. 
Appiov fragment tak podl'a Michela Humma zhŕňa pytagorejské učenie Archyta z Tarentu, ktorý však pravdepodobne myšlienkovo vychádzal z ešte staršej Aristoxenovej tradície. Francúzsky bádatel' okrem toho podopiera pytagorejský pôvod frag-

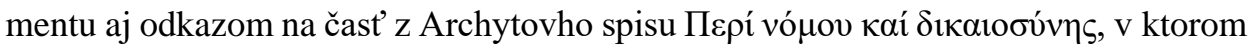
sa problematizuje práve sila vlády rozumu:

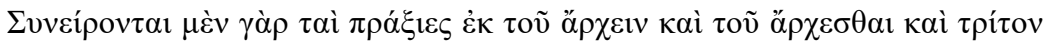

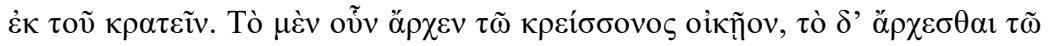

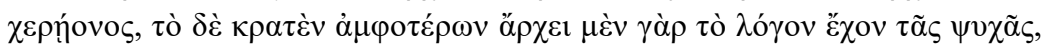

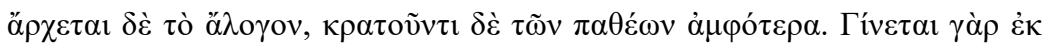

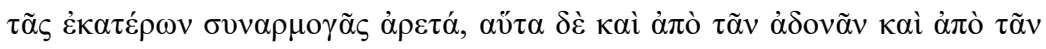

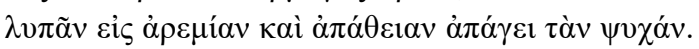

„Existuje súvislost' medzi tým, ako sa v nás prejavuje schopnost' vládnut', schopnost' dat' sa ovládat' a tým, ako sa v nás prejavuje zvrchovaná sila. Vládnutie je znakom lepšieho, nechat' sa ovládat' by malo byt' vlastnost'ou horšieho a zvrchovaná sila by mala v sebe zhrňovat' obe. Vládne totiž čast' duše obsahujúca rozum, ovládaná je jej čast' bez rozumu, pričom zvrchovanú silu nejako vytvárajú oba tieto duševné stavy. Prepojením jedného s druhým totiž vzniká cnost'. Tá odvádza dušu tak od rozkoší, ako aj od smútkov, a privádza ju k upokojeniu a k stavu ne-

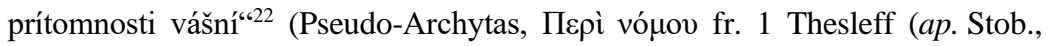
Flor., IV, 1, 135 (p. 82 H.) = 43, 132 M.) (Humm 2005, 533).

Appiov fragment však vôbec nemusí byt' primárne spájaný s filozofiou pytagoreizmu, tak ako si myslí Michel Humm. Z obsahového hl'adiska zjavne tematizuje problematiku l'udského sebaovládania nad rozkošami a pripomína skôr obecné moralistické ponaučenia známe z gréckej literatúry. Na to okrem iných autorov ${ }^{23}$ nakoniec poukazuje aj sám Michel Humm, ktorý zdôrazňuje spätost' uvedenej pasáže s čast’ami diel autorov takzvanej novej komédie, najmä Filémóna a Menandra (Humm 2005, 524 - 526). Franz Stoessl okrem toho upozorňuje na nápadnú obsahovú podobnost' Appiovho textu s častou Solónovho fragmentu (Solón, zl. 6, 3-4):

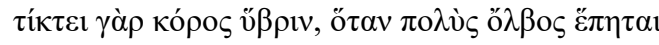

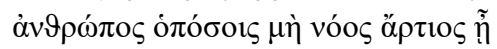

„Lebo z bujnosti spupnost' sa rodí, ked’ nadobudne náhle vel'kého bohatstva ten, kto nemá právny cit...“24

${ }^{22}$ Preklad Andreja Kalaša.

${ }^{23}$ Marx (1897, 220); Stoessl (1979, 21); Maurach (2006, 10).

${ }^{24}$ Citované a upravené do slovenského jazyka podl’a Hošek 1981, 75. 


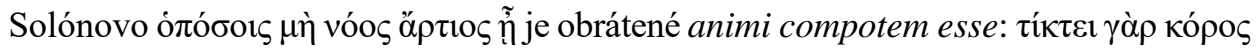
űpıv: ferocia pariat: v̋ßpı quid fraudis stuprique. Podobnú myšlienku zároveň nachádzame aj u Theognida ${ }^{25}$ (Stoessl 1979, 21).

Vo všetkých týchto textoch sa rieši problematika prudkosti bohatých l'udí, ktorí po nadobudnutí majetku majú problém s dodržiavaním zákona a môžu sa tak dopúšt’at' morálnych prehreškov. To je tematickou náplňou tak Solónových a Theognidových veršov, ako aj námetov čerpajúcich z novej komédie. Appius zjavne nie je originálny myslitel'. S najväčšou pravdepodobnost'ou vo svojom diele reprodukoval populárno-filozofické sentencie mravného charakteru, ktorých prameňom mohli byt' zbierky gréckych výrokov známe ako Gnomologion (Marx 1897, 220). Skutočná podoba literárneho diela Appia Claudia Caeca tak mohla mat' podobu zbierky krátkych citácií, ktoré autor excerpoval z nejakého staršieho gréckeho zdroja a následne tvorivo spracoval. To by v konečnom dôsledku vysvetl'ovalo aj skutočnost', prečo sa názov jeho diela zachoval tradovaný v podobe Sententiae, Carmen či Carmina (Humm 2005, 526). V takejto zbierke gréckych výrokov mohli byt' uvedené výroky z rôznych zdrojov, ale presne určit’ pôvod či textovú väzbu týchto zlomkov - tak ako sa o to usiluje Michel Humm - nie je podl’a nášho názoru možné. To, že Appius mohol čerpat' z rozmanitej literárnej tradície, dokladá nakoniec aj fakt, že v prípade hladania myšlienkových zdrojov fragmentu 2 a 3 sa taktiež v odbornej literatúre objavujú intertextuálne väzby najmä na texty gréckej tragédie či novej komédie. $^{26}$

\section{Záver}

Keby bol tento predpoklad správny, otázka pytagorejského pôvodu Appiovho myslenia by bola značne problematická. Ako sme sa snažili ukázat', obsahová stránka fragmentu 1 sa dá interpretovat' aj bez spájania autorovej filozofie s pytagoreizmom. Okrem toho sám Cicero, ktorý ako jediný spomína pytagorejský pôvod Appiovej básne, nikde bližšie nevysvetl'uje tento predpoklad. Podl’a nášho názoru zjavne účelne využíva dobrú povest' Appiovej osoby, aby ňou dokázal starobylost' rímskej filozofickej tradície.

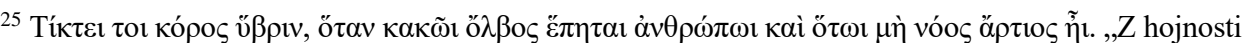
rodí sa pýcha, ked' zloduch má vel'ké bohatstvo, pritom však chýba mu rozum, aký by správne mal mat"“. (Theognis I, 153 - 154; Citované a upravené do slovenského jazyka podl’a Hošek 1981, 145). ${ }^{26}$ Pozri bližšie Marx (1987); Stoessl (1979); Maurach (2006, $\left.10-11\right)$.
} 
Problematickost' Appia ako pytagorejského filozofa však nespochybňuje jeho primárny význam pre počiatky výkladu dejín rímskej filozofie. Všetky tri fragmenty sa svojím obsahom vzt’ahujú k praktickej archaickej múdrosti a Appius si ich zrejme vybral z toho dôvodu, aby prostredníctvom nich demonštroval hodnotu rímskych mores maiorum. Tieto krátke texty pripomínajú sententiae, ktoré sa v prípade gréckej filozofie pripisujú legendárnym siedmim mudrcom. Tak ako grécka filozofická tradícia projektovala počiatky filozofického myslenia do týchto postáv, rímska filozofická tradícia pravdepodobne urobila niečo podobné s Appiom Claudiom Caecom. Appius svojím praktickým životom učenca, reformátora a hlásatel’a archaickej morálky je akýmsi náprotivkom uvedenej gréckej tradície. Výklad dejín rímskej filozofie by sa tak mohol začínat' práve Appiom, pretože práve on svojou legendárnou osobnost'ou, literárnym dielom a spôsobom, ako s ním zaobchádzala neskoršia literárna tradícia, zosobňuje charakteristické črty antického protofilozofického myslenia.

\section{Literatúra}

DUTSCH, D. (2014): The Beginnings: Philosophy in Roman Literature before 155 B. C. In: Garani, M. - Konstan, D. (eds.): The Philosophizing Muse: The Influence of Greek Philosophy on Roman Poetry. Cambridge: Cambridge Scholar Publishing.

FORSYTHE, G. (1991): A Philological Note on the Scipionic Circle. The American Journal of Philology, 112 (3), $363-364$.

BAEHRENS, E. - MOREL, W. (eds.) (1927): Fragmenta Poetarum Latinorum Epicorum et Lyricorum. Lipsiae: In aedibus B. G. Teubneri.

GRIFFIN, M. (2005): Philosophy, Politics, and Politicians at Rome. In: Griffin, M. - Barnes, J. (eds.): Philosophia Togata I. Oxford: Clarendon Press.

HOBZA, P. (2007): Mílétské texty jako svědectví filosofie? Acta Universitatis Palackianae Olomucensis, Facultas Philosophica, Philosophica VII, 23 - 34.

HORKY, P. S. (2011): Herennius Pontius: The Construction of a Samnite Philosopher. Classical Antiquity, 30 (1), 119 - 147. DOI: https://doi.org/10.1525/ca.2011.30.1.119

HOŠEK, R. (ed.) (1981): Nejstarši řecká lyrika. Překlad F. Stiebitz, F. Novotný, P. Oliva, R. Hošek, R. Mertlík. Praha: Svoboda.

HUMM, M. (2005): Appius Claudius Caecus. La République accomplie. Rome: Bibliothèque des Écoles Française de Rome. DOI: https://doi.org/10.4000/books.efr.1581

HUMM, M. (2000): Una sententia pitagorica di Appio Claudio? In: Ghidini, M. T., Marino, A. S., Visconti, A.: Tra Orfeo e Pitagora. Origini e incontri di culture nell'antichità. Napoli: Bibliopolis.

KALAŠ, A. (2017): Filozofické aspekty Horáciovho diela. Filozofia, 72 (2), 114 - 127.

MARX, F. (1897): Appius Claudius und Philemon. Zeitschrift für die österreichischen Gymnasien $48,217-220$.

MAURACH, G. (2006): Geschichte der römischen Philosophie. Darmstadt: Wissenschaftliche Buchgesellschaft.

MENDELL. C. W. (1920): Satire as Popular Philosophy. Classical Philology, 15 (2), 138 - 157.

MORFORD, M. (2002): The Roman Philosophers. London and New York: Routledge Taylor \& Francis Group.

PORUBJAK, M. (2013): Predstava l'udskej prirodzenosti v theognidei. Filozofia, 68 (4), 276 - 284. 
PORUBJAK, M. (2012): Tyrtaios a sociálno-politická funkcia reciprocity. Filozofia, 67 (1), 35 - 46.

POWELL, J. (2003): The Embassy of the Three Philosophers to Rome in 155 BC. In: Kremmydas, Ch. - Tempest, K. (eds.): Hellenistic Oratory. Oxford: Oxford University Press, 219 - 247. DOI: https://doi.org/10.1093/acprof:oso/9780199654314.001.0001

RASCHKE, W. J. (1990): The Virtue of Lucilius. Latomus. T. 49, Fasc. 2, 352 - 369.

SHARROCK, A. (2013): Terence and Non-Comic Intertexts. In: Augoustakis, A. - Traill, A. (eds.): A Companion to Terence. Wiley-Blackwell, 52 - 68. DOI: https://doi.org/10.1002/9781118301975

STANKIEWICZ, L. (2008): A duch jego był napięty jak łuk. Symbolae Philologorum Posnaniensium, XVIII, 215 - 221.

STOESSL, F. (1979): Die Sententiae des Appius Claudius Caecus. Rheinisches Museum für Philologie, Neue Folge. 122. Bd., H. 1, 18 - 23.

STRASBURGER, H. (1966): Der Scipionenkreis. Hermes, 94, 60 - 72.

URBANCOVÁ, E. (2003): M. Tullius Cicero a tvorba latinského filozofického slovníka. Filozofia, $58(8), 513-522$

ZETZEL, J. (1972): Cicero and the Scipionic Circle. Harvard Studies in Classical Philology, 76, $173-179$

Príspevok vznikol na Katedre filozofie a aplikovanej filozofie FF UCM v Trnave ako súčast' riešenia grantových úloh VEGA 1/0864/18 Ad Fontes Cynicorum Socraticorum-pramene a interpretácia sokratovského kynizmu a FPPV-15-2020.

Peter Fraňo

Katedra filozofie a aplikovanej filozofie

Filozofická fakulta UCM

Nám. J. Herdu 2

91701 Trnava

Slovenská republika

e-mail: peter.frano@ucm.sk

ORCID ID: https://orcid.org/0000-0002-0909-2699 